Удк 818-001.17-099-07

DOI 10.11603/2414-4533.2019.1.9907

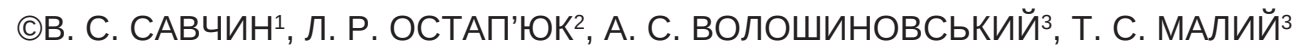

Комунальна міська клінічна лікарня № $8^{1}$, Львів

Вінницький національний медичний університет ${ }^{2}$

Львівський національний університет імені Івана Франка ${ }^{3}$

\title{
Новий погляд на питання діагностики ендогенної інтоксикації у хворих з опіковою травмою
}

\begin{abstract}
Мета роботи: діагностика запальних змін у хворих з опіковою травмою в рамках методу флуоресцентної спектроскопії. Матеріали і методи. Клінічною базою дослідження сироватки крові (СК) хворих із опіковою травмою було опікове відділення Комунальної міської клінічної лікарні № 8 м. Львова. Експериментальна база - лабораторія люмінесценції кафедри експериментальної фізики Львівського національного університету імені Івана Франка. Об'єктами дослідження були 48 проб CK 10 пацієнтів віком від 24 до 58 років (7 чоловічої статі і 3 жіночої) з опіками полум’ям та окропом I-IIA-IIБ ступеня загальною площею від 18 до 45 \% поверхні тіла, в тому числі голови та шиї.

Результати досліджень та їх обговорення. Вивчено спектри флуоресценції (СФ) СК хворих з опіковою травмою, які являють $\lambda$-подібні криві у діапазоні 300 нм $<\lambda<450$ нм. Основними показниками, які використано для аналізу СФ СК, є інтенсивність флуоресценції $\left(\mathrm{I}_{\phi}\right)$ та положення максимуму смуги флуоресценції $\left(\lambda_{\max }\right)$. Дослідження СК розпочиналися при появі загрозливих ознак щодо розвитку гнійно-септичних ускладнень і проводилося в динаміці з інтервалом 3-8 днів аж до одужання.
\end{abstract}

Ключові слова: опікова травма; сепсис; метод флуоресцентної спектроскопії.

Постановка проблеми і аналіз останніх досліджень та публікацій. Проблема діагностики захворювань є пріоритетною у медичній практиці, адже це запорука їх вчасного виявлення, адекватного лікування і видужування пацієнтів, але більшість сучасних лабораторних та інструментальних методів обстеження $€$ репрезентативними на фоні вже маніфестуючих проявів патологічних процесів. Для хворих із термічною травмою гнійно-запальні захворювання і сепсис, які супроводжуються ендогенною інтоксикацією, $є$ основними причинами летальності. При цьому запускається ланцюг патологічних реакцій, які втрачають природний контроль [1]. Ми попередньо вивчали можливості вдосконалення лікувальної тактики при опіковій травмі шляхом дослідження ефективності застосування сучасних методів місцевого лікування на розвиток клітинної фази запальної реакції у хворих $з$ опіками полум'ям та окропом I-IIА-ІІБ ступеня загальною площею від 18 до 45 \% поверхні тіла, в тому числі голови та шиї [2, 3].

Для вирішення проблеми ендогенної інтоксикації організму при опіковій травмі важливою $є$ детоксикація молекул альбуміну, що виконують ряд дуже важливих функцій, зокрема і транспортну. Оскільки частина зв'язуючих центрів альбуміну стає заблокованою токсинами, його реальна “ефективна" концентрація $€$ значно нижчою [4]. При проведенні лікування, окрім хірургічних втручань та антибактеріальної терапії, важливою його складовою $є$ інфузійна терапія, в тому числі 3 використанням розчинів альбуміну [5]. Сучасні методи, що входять до складу загальноприйнятих алгоритмів для діагностики ендогенної інтоксикації в закладах охорони здоров'я, не забезпечують виявлення “ефективної” концентрації альбуміну, а ті, що використовуються, дають можливість діагностувати захворювання лише при наявності вже розгорнутої клінічної картини, що значно погіршує прогноз. Тому актуальними є два аспекти вирішення проблеми гнійно-септичних ускладнень при опіковій травмі, а саме: можливість їх ранньої діагностики та оцінка ризику виникнення сепсису в цій ситуації.

Для розширення сучасного арсеналу діагностичних методів протягом останніх десятиліть велика увага у медичній практиці приділялась використанню фізичних методів дослідження [6]. Метод флуоресцентної спектроскопії (МФС) є неінвазивним способом дослідження люмінесцентних характеристик різних об'єктів, який широко використовується для проведення новітніх перспективних досліджень і дає змогу виявити патологічні процеси в живих організмах на ранній стадії їх розвитку. Основними перевагами цього методу $є$ простота, експресність, висока чутливість та точність, а також можливість неруйнівного контролю за біологічними об'єктами та середовищами.

У попередніх роботах проводили апробацію використання МФС для діагностики гнійно-запальних ускладнень та сепсису в хірургічній [7] та акушерсько-гінекологічній [8] практиці. Показано, що структура спектрів флуоресценції (СФ) сиро- 
ватки крові $(\mathrm{CK})$ є ефективним маркером тяжкості захворювання, який дає змогу швидко та якісно оцінити загрозу виникнення критичних гнійносептичних ускладнень і здійснювати моніторинг лікувального процесу. Зміни спектрально-флуоресцентних характеристик СК фіксували за 2448 год до появи очевидних клініко-лабораторних ознак суттєвої зміни загальносоматичного статусу хворих [4]. Враховуючи спільність патогенезу розвитку синдрому системної запальної відповіді при опіковій травмі та сепсисі, незважаючи на їх різні етіологічні чинники та наш успішний досвід використання МФС для діагностики гнійно-септичних станів у медичній практиці [5-8], ми будемо використовувати цей метод для діагностики ендогенної інтоксикації при опіковій травмі.

Мета роботи: діагностика запальних змін у хворих з опіковою травмою в рамках методу флуоресцентної спектроскопії.

Матеріали і методи. Клінічною базою дослідження СК хворих з опіковою травмою було опікове відділення Комунальної 8-ї міської клінічної лікарні м. Львова. Експериментальною базою була лабораторія люмінесценції кафедри експериментальної фізики Львівського національного університету імені Івана Франка. Об’єктами дослідження були проби СК пацієнтів. У вибірку були включені тяжкохворі 3 поверхневими опіками полум'ям та окропом I-IIA-ІІБ ступеня, в тому числі голови та шиї. В рамках МФС проведено дослідження СФ 48 проб СК 10 хворих. Дослідження СК розпочинали при появі загрозливих ознак щодо розвитку гнійно-септичних ускладнень ознак і проводилося в динаміці з інтервалом 3-8 днів і перед виписуванням зі стаціонару. При цьому проводився постійний моніторинг клінічних показників, результатів лабораторних обстежень, в тому числі і основних біохімічних показників крові. Люмінесцентні дослідження СК, результати яких наведені в цій роботі, проводили 3 використанням оптичних монохроматорів МДР-2 та МДР-12. Беручи до уваги ці дані та результати для СФ СК, проводилося корегування лікувальних заходів з метою підвищення їх ефективності.
Результати досліджень та ї обговорення. Збудження зразків СК ультрафіолетовим світлом $\left(\lambda_{36}=280\right.$ нм $)$ дає змогу досліджувати свічення наявних у СФ пацієнтів з опіковою хворобою, які являють $\lambda$-подібні криві в діапазоні 300 нм $<\lambda<450$ нм. Основними показниками, які використали для аналізу СФ СК, $є$ інтенсивність флуоресценції $\left(\mathrm{I}_{\phi}\right)$ і положення максимуму смуги флуоресценції $\left(\lambda_{\max }\right)[6]$. Оскільки флуоресценція СК зумовлена альбумінами, тому будь-які зміни СФ можна пояснити з точки зору зміни структури значної частини молекули альбуміну. При синдромі ендогенної інтоксикації в організмі створюються умови для утворення форм альбуміну зі зміненими фізико-хімічними властивостями. Оскільки альбумін має здатність до комплексоутворення, то частина його молекул зв'язує токсичні продукти метаболізму бактерій. Ці молекули альбуміну заблоковують токсини, тому їх зв'язуюча здатність відносно фізіологічних ліганд i лікарських препаратів зменшується. Таким чином, ефективна концентрація альбуміну знижується, хоча його загальна концентрація залишається сталою величиною.Спектрально-флуоресцентні характеристики СК відображають вплив на організм хворих різних факторів (бактеріємії, антибактеріальної та інфузійної терапії). Для поглибленого розуміння впливу лікувальних заходів на СФ СК перед початком використання МФС in vivo були попередньо проведені експерименти in vitro, в рамках яких було вивчено вплив бактеріємії та інфузійної терапії на зміну спектрально-флуоресцентних характеристик СК. Також у даній роботі експериментально доведено можливість використання $20 \%$ донорського альбуміну як еталону при дослідженні СФ СК хворих [9].

Для оцінки поведінки отриманих спектрально-флуоресцентних характеристик СК пацієнтів для прикладу детально проаналізуємо результати отриманих у динаміці досліджень $\mathrm{I}_{\phi}$ i $\lambda_{\max }$ СФ СК двох хворих у тяжкому стані, представлених у таблицях $1,2$. У таблиці 1 представлено результати досліджень у динаміці основних спектральнофлуоресцентних характеристик хворого з опіковою травмою, який госпіталізований в стаціонар 27.06.2015 p.

Таблиця 1. Результати досліджень у динаміці основних спектрально-фрлуоресцентних характеристик хворого $з$ опіковою травмою

\begin{tabular}{||l|c|c|c|c|c|c|c|c|c|c|c||}
\hline \multicolumn{1}{|c|}{$\mathbf{N}$} & а & 1.1 & 1.2 & 1.3 & 1.4 & 1.5 & 1.6 & $1^{\prime}$ & $2^{\prime}$ & $3^{\prime}$ & $4^{\prime}$ \\
\hline Дата & 3.07. & 3.07. & 8.07. & 13.07. & 17.07. & 20.07. & 24.07. & 03.06 & 05.06 & 06.06 & 07.06 \\
\hline$\lambda_{\max }$ нм & 327 & 336,1 & 332,2 & 341,1 & 335,1 & 333,1 & 335,1 & 335,2 & 335,2 & 334,1 & 331,6 \\
\hline I, в. о. & 1 & 0,88 & 0,88 & 0,35 & 0,64 & 0,76 & 0,80 & 0,63 & 0,43 & 0,14 & 0,40 \\
\hline
\end{tabular}


На основі мікробіологічного дослідження у хворого було верифіковано Staphyloccus aureus $10^{5}$ та Pseudomonas aeruginosa $10^{6}$. Хворому відразу призначили відповідне лікування, в тому числі й антибіотикотерапію та інфузійну терапію об'ємом 2-3 л щодня, в тому числі й $20 \%$ розчин донорського альбуміну (по 100 мл 8 разів у різні дні). За рахунок отримання інфузійної терапії інтенсивність СФ СК цього хворого не була помітно знижена $\left(\mathrm{I}_{\phi}=0,88\right.$ в.о.), що корелює з результатами дослідження in vitro [9]. При цьому не було зафіксовано також помітного зсуву його СФ СК у довгохвильову область, незважаючи на верифікацію у нього кількох збудників. Очевидно, що приймання достатньої кількості альбуміну дозволив на цей час значно покращити роботу детоксикаційних систем організму, що позитивно вплинуло на спектрально-флуоресцентні показники. Критичним моментом під час моніто- рингу СФ СК цього хворого стало 13.07.2015 р., коли мало місце суттєве зниження $\mathrm{I}_{\phi}$ до 0,35 в.о. та зсув СФ у довгохвильову область на 9 нм. Ці показники добре корелюють з відповідними результатами дослідження СФ СК хворого на сепсис, (1'-4'), що, найімовірніше, пов'язане з припиненням в даний час інфузії розчину альбуміну. Відновлення інфузії розчину альбуміну сприяло при наступних заборах крові 17.07.-24.07.2015 р. (1.5-1.6) до значного покращення спектральнофлуоресцентних показників СК. Вони добре корелювали з клінічними показниками і результатами лабораторних обстежень хворого. Тому хворого виписали зі стаціонару в задовільному стані 24.07.2015 p.

У таблиці 2 представлено в динаміці результати дослідження спектрально-флуоресцентних характеристик СК хворого з опіковою травмою, який перебував на стаціонарному лікуванні в 2017 році.

Таблиця 2. Результати дослідження спектрально-фрлуоресцентних характеристик сироватки крові хворого з опіковою травмою

\begin{tabular}{||l|c|c|c|c|c|c|c|c|c|c||}
\hline \hline \multicolumn{1}{|c|}{$\mathrm{N}$} & а & Д & $1^{\prime}$ & 2.1 & 2.2 & 2.3 & 2.4 & 2.5 & 2.6 & 2.7 \\
\hline Дата & 06.06. & 06.06. & 06.06. & 9.02. & 14.02. & 22.02. & 27.02. & 03.03. & 10.03. & 31.03. \\
\hline$\lambda_{\max }$ нм & 330,1 & 333,1 & 333 & 335,1 & 339,1 & 337 & 334 & 335,1 & 331,1 & 332,0 \\
\hline I, в.о. & 1 & 1 & 0.16 & 0,41 & 0,37 & 0,46 & 0,61 & 0,79 & 0,89 & 0,95 \\
\hline
\end{tabular}

Після госпіталізації в стаціонар хворому виконано інфузійну терапію у значному об'ємі (до 2 л щодня) та інфузії $10 \%$ розчину донорського альбуміну (06.02, 10.02, 15.02, 18.02). Однак $\mathrm{I}_{\phi}$ його СК була низькою $(9.02-0,41$ в. о., а $14.02-$ 0,37 в. о.), оскільки стан хворого був дуже тяжкий. На фоні подальшого лікування, в тому числі й ефективної антибіотикотерапії, $\mathrm{I}_{\phi}$ зросла до 0.46 в. о. (22.02). Цей момент був ключовим для формування подальших позитивних тенденцій динаміки стану хворого та поведінки спектрально-флуоресцентних характеристик його СК. При подальшому лікуванні на фоні його поступового одужання навіть після відміни інфузійної терапії показники $\mathrm{I}_{\phi}$ поступово зросли з 0,61 до 0,95 в. о. Отримані результати $\mathrm{I}_{\phi}$ та $\lambda_{\max }$ добре корелювали з клінічними та лабораторними показниками хворого і хворого виписали зі стаціонару 31.03.2017 р. у задовільному стані. Аналогічний характер кореляції спектрально-флуоресцентних характеристик СК та клінічних і лабораторних показників має місце і для інших хворих, які розглядалися в даній статті.

Висновки. Структура спектрів флуоресценції сироватки крові, величини інтенсивностей флуоресценції та положення максимумів хворих, які розглядалися в даній роботі, є ефективними маркерами тяжкості захворювання та його прогнозування, які дають змогу оперативно та якісно оцінити загрозу виникнення критичних гнійно-септичних ускладнень, здійснювати моніторинг лікувального процесу та проводити контроль його ефективності з метою запобігання розвитку сепсису. МФС суттєво доповнює інформацію щодо результатів інших методів дослідження на основі патогенетичного осмислення процесів, які мають місце в організмі людини при гнійно-запальних захворюваннях і щодо можливості надання прогностичної оцінки. 


\section{ОРИГІНАЛЬНІ ДОСЛІДЖЕННЯ}

\section{СПИСОК ЛІТЕРАТУРИ}

1. Коваленко О. М. Патогенетичне обгрунтування програм хірургічного лікування дітей з поширеними опіками та вплив їх на перебіг ранового процесу: дис. ... д-ра мед. наук : 14.01.03 / О. М. Коваленко. - К., 2012. - 352 с.

2. Савчин В. С. Особливості репаративних процесів у хворих з глибокими опіками голови та шиї / В. С. Савчин // Архів клінічної та експериментальної медицини. - 2014. - Т. 23, № 2. - С. 149-152.

3. Савчин В. С. Особливості запальної відповіді при опіковій травмі голови і шиї / В. С. Савчин // Архів клінічної медицини. - 2014. - № 2 (частина 2). - С. 112-113.

4. Пат. № 76953 Україна А61B 17/00 G01N 33/48, G01N 21/64 Спосіб ранньої діагностики гнійно-септичних ускладнень за допомогою методу флуоресцентної спектроскопії / Герич І. Д., Булавенко О. В., Остап’юк Л. Р., Волошиновський А. С., Мягкота С. В., заявник та патентовласник Вінницький національний медичний університет. - № 201207441; заявл. 19.06. 2012 ; опубл. 25.01.2013, Бюл. № 2 .

5. Апробація методу флуоресцентної спектроскопії для ді-

\section{REFERENCES}

1. Kovalenko, O.M. (2012). Patohenetychne obhruntuvannia prohram khirurhichnoho likuvannia ditei z poshyrenymy opikamy ta vplyv yikh na perebih ranovoho protsesu [Pathogenetic substantiation of programs of surgical treatment of children with common burns and their influence on the course of wound process]. Doctor's thesis. Kyiv: O. Bohomolets National Medical University [in Ukrainian].

2. Savchyn, V.S. (2014). Osoblyvosti reparatyvnykh protsesiv u khvorykh z hlybokymy opikamy holovy ta shyi [Features of reparative processes in patients with deep burns of the head and neck]. Arkhiv klinichnoi ta eksperymentalnoi medytsyny Archive of Clinical and Experimental Medicine, 23 (2), 149-152 [in Ukrainian].

3. Savchyn, V.S. (2014). Osoblyvosti zapalnoi vidpovidi pry opikovii travmi holovy $i$ shyi [Features of the inflammatory response when burn injury to the head and neck]. Arkhiv klinichnoi medytsyny - Archive of Clinical Medicine, 2 (2), 112113 [in Ukrainian].

4. Pat. №76953 Ukraina A61V 17/00 G01N 33/48, G01N 21/64 (2013). Sposib rannoi diahnostyky hniino-septychnykh uskladnen za dopomohoiu metodu fluorestsentnoi spektroskopii [Method of early diagnosis of purulent-septic complications using the method of fluorescence spectroscopy]. Herych I.D., Bulavenko O.V., Ostapiuk L.R., Voloshynovskyi A.S., Miahkota S.V., zaiavnyk ta patentovlasnyk Vinnytskyi natsionalnyi medychnyi universytet. № 201207441, Biul. № 2 [in Ukrainian].

5. Savchyn, V.S., Ostapiuk, L.R., Voloshynovskyi A.S., \& Malyi, T.S. (2016). Aprobatsiia metodu fluorestsentnoi агностики ендогенної інтоксикації при опіковій травмі / В. С. Савчин, Л. Р. Остап’юк, А. С. Волошиновський [та ін.] // Клінічна хірургія. - 2016. - С. 68-70.

6. Флуоресцентна спектроскопія: можливості застосування в медичній практиці / [І. Д. Герич, О. В. Булавенко, Л. Р. Остап’юк та ін.]. - Л. : Ліга-Прес, 2015. - 366 с.

7. Gerych I. Spectral-fluorescent properties of serum as a reliable marker for early diagnosis of sepsis / I. Gerych, O. Bulavenko, L. Ostapiuk // Journal of Gynecology and Obstetrics. - 2014. Vol. 2, No. 5. - P. 71-74. [Electronic resource]. Mode access : doi: $10.11648 /$ j.jgo.20140205.11.

8. Обгрунтування доцільності застосування методу флуоресцентної спектроскопії в комплексній діагностиці післяпологового ендометриту / О. В. Булавенко, Л. Р. Остап’юк, В. О. Рудь [та ін.] // Здоровье женщины. - Київ, 2016. № 3(109). - С. 71-75.

9. Моделювання змін сироватки крові при різних захворюваннях та лікувальних заходах / О. В. Булавенко, І. Д. Герич, Л. Р. Остап'юк [та ін.] // Biomedical and biosocial anthropology. - 2013. - T. 20. - C. 8-14.

spektroskopii dlia diahnostyky endohennoi intoksykatsii pry opikovii travmi [Approbation of the fluorescence spectroscopy method for the diagnosis of endogenous intoxication with burn injury]. Klinichna khirurhiia - Clinical Surgery, 6, 68-70 [in Ukrainian].

6. Herych, I.D., Bulavenko, O.V., Ostapiuk, L.R., Voloshynovskyi, A.S., \& Miahkota, S.V. (2015). Fluorestsentna spektroskopiia: mozhlyvosti zastosuvannia $v$ medychnii praktytsi [Fluorescent Spectroscopy: ability to use in medical practice]. Lviv: Liha-Pres [in Ukrainian].

7. Herych, I., Bulavenko, O., \& Ostapiuk, L. (2014). Spectralfluorescent properties of serum as a reliable marker for early diagnosis of sepsis. Journal of Gynecology and Obstetrics, 2(5), 71-74 [Electronic resource]. Retrieved from: doi: 10.11648/j. jgo.20140205.11.

8. Bulavenko, O.V, Ostapiuk, L.R., Rud, V.O., Voloshynovskyi, A.S. (2016). Obhruntuvannia dotsilnosti zastosuvannia metodu fluorestsentnoi spektroskopii $v$ kompleksnii diahnostytsi pisliapolohovoho endometrytu [Rationale of the method of fluorescence spectroscopy in complex diagnosis of postpartum endometritis]. Zdorovye zhenshchiny - Health of a Woman, 3 (109), 71-75 [in Ukrainian].

9. Bulavenko, O.V., Herych, I.D., Ostapiuk, L.R., Vashchuk V.V., Voloshynovskyi, A.S., \& Miahkota, S.V. (2013). Modeliuvannia zmin syrovatky krovi pry riznykh zakhvoriuvanniakh ta likuvalnykh zakhodakh [Modeling changes in serum for different diseases and medical events]. Biomedical and biosocial anthropology - Biomedical and Biosocial Anthropology, 20, 8-14 [in Ukrainian]. 
Municipal City Clinical Hospital No. 8, Lviv

Vinnytsia National Medical University

Ivan Franko Lviv National University

\section{A NEW LOOK AT THE ISSUE OF DIAGNOSTICS OF ENDOGENOUS INTOXICATION IN PATIENTS WITH BURN INJURY}

The aim of the work: to diagnose the inflammatory changes in patients with burn injury in the framework of the method of fluorescence spectroscopy.

Materials and Methods. The clinical base of blood serum (BS) test for patients with burn injury was the Burn Department of the Communal City Clinical Hospital No.8 in Lviv. The experimental base was the Luminescence Laboratory of the Experimental Physics Department at the Ivan Franko Lviv National University. The subjects of the study were 48 samples of BS of 10 patients from 24 to 58 years old ( 7 males and 3 females) with burns of flame and boiling water of I-IIA-IIB degree in the total area from 18 to $45 \%$ of the body surface, including head and neck.

Research and Discussion. Fluorescence spectra (FS) of BS of patients with burn injury, which are $\lambda$-like curves in the range of $300 \mathrm{~nm}<\lambda<450 \mathrm{~nm}$, were studied. The main indicators that were used for the analysis of FS of BS are the fluorescence intensity ( $\mathrm{I}_{\mathrm{f}}$ ) and the position of the maximum of fluorescence band $\left(\lambda_{\max }\right)$. FS studies began with the emergence of threatening signs of development of purulent-septic complications and were conducted in a dynamics with an interval of 3-8 days until recovery.

Key words: burn injury; sepsis; method of fluorescence spectroscopy.

\section{В. С. САВЧИН ${ }^{1}$, Л. Р. ОСТАПЮК², А. С. ВОЛОШИНОВСКИЙЗ , Т. С. МАЛЫЙ}

Коммунальная городская клиническая больница № $8^{1}$, Львов Винницкий национальный медицинский университет ${ }^{2}$

Львовский национальный университет имени Ивана Франка ${ }^{3}$

\section{НОВЫЙ ВЗГЛЯД НА ВОПРОСЫ ДИАГНОСТИКИ ЭНДОГЕННОЙ ИНТОКСИКАЦИИ У БОЛЬНЫХ С ОжОГОВОЙ ТРАВМой}

Цель работы: диагностика воспалительных изменений у больных с ожоговой травмой в рамках метода флуоресцентной спектроскопии.

Материалы и методы. Клинической базой исследования сыворотки крови (СК) больных с ожоговой травмой было ожоговое отделение Коммунальной городской клинической больницы № 8 города Львова. Экспериментальная база - лаборатория люминесценции кафедры экспериментальной физики Львовского национального университета имени Ивана Франка. Объектами исследования были 48 проб СК 10 пациентов в возрасте от 24 до 58 лет, (7 мужского пола и 3 женского) с ожогами пламенем и кипятком I-IIA-ІІБ степени общей площадью от 18 до 45 \% поверхности тела, в том числе головы и шеи.

Результаты исследований и их обсуждение. Изучены спектры флуоресценции (СФ) СК больных с ожоговой травмой, которые представляют собой $\lambda$-образные кривые в диапазоне 300 нм $<\lambda<450$ нм. Основными показателями, которые были использованы для анализа СФ СК, является интенсивность флуоресценции (I $)$ и положение максимума полосы флуоресценции $\left(\lambda_{\max }\right)$. Исследование СК начинались при появлении угрожающих признаков по развитию гнойно-септических осложнений и проводилось в динамике с интервалом 3-8 дней до выздоровления.

Ключевые слова: ожоговая травма; сепсис; метод флуоресцентной спектроскопии. 